\title{
Perbandingan hasil belajar matematika peserta didik menggunakan pendekatan realistic mathematics education dengan pendekatan saintifik di SMP Negeri 14 Kota Bengkulu
}

\author{
Agung Wibowo*, Hanifah, Effie Efrida Muchlis \\ Program Studi Pendidikan Matematika JPMIPA FKIP Universitas Bengkulu \\ *agungwibowo539@gmail.com
}

DOI: https://doi.org/10.33369/pendipa.3.3.125-131

\begin{abstract}
[Comparison of Student Learning Outcomes in mathematics using Realistic Mathematics Education Approach and Scientific Approach in SMP Negeri 14 Kota Bengkulu] The aim of this research was to find out whether student learning outcomes in mathematics using Realistic Mathematics Education (RME) approach better than student learning outcomes in mathematics using scientific approach in grade VII Junior High School Number 14 Bengkulu City academic year 2018/2019. The type of this research was Quasi Experiment Research with Nonequivalent Posttest-Only Control Group Design. The population of this research were all of student grade VII Junior High School Number 14 Bengkulu City academic year 2018/2019. The sample taken with cluster random sampling technique so that the class VII 5 was obtained as Realistics Mathematics Education (RME) approach class with 26 students and class VII 6 was obtained as scientific approach class with 26 students. The instrument of this research was student learning outcomes test sheet in an essay form. The average student lerning outcomes in mathematics using Realistic Mathematics Education (RME) approach is 53,5 and The average student lerning outcomes in mathematics using Scientific approach is 43,54. This research showed that student learning outcomes in mathematics using Realistic Mathematics Education (RME) approach better than student learning outcomes in mathematics using scientific approach in grade VII Junior High School Number 14 Bengkulu City, with $t_{\text {count }}=2,689441>t_{\text {table }}=2,008559$.
\end{abstract}

Keywords: learning outcomes in mathematics; realistic mathematics education (rme) approach; scientific approach.

(Received September 4, 2019; Accepted September 26, 2019; Published October 8, 2019)

\begin{abstract}
ABSTRAK
Tujuan penelitian ini adalah untuk mengetahui apakah hasil belajar matematika peserta didik menggunakan pendekatan Realistic Mathematics Education (RME) lebih baik dari hasil belajar matematika peserta didik menggunakan pendekatan saintifik di Kelas VII SMP Negeri 14 Kota Bengkulu tahun pelajaran 2018/2019. Jenis penelitian ini adalah Quasi Experiment Research (Penelitian Eksperimen Semu) dengan desain penelitian nonequivalent Posttest-Only Control Group Design. Populasi dalam penelitian ini adalah seluruh siswa kelas VII SMP Negeri 14 Kota Bengkulu tahun pelajaran 2018/2019. Sampel diambil dengan menggunakan teknik cluster random sampling sehingga diperoleh kelas VII 5 sebagai kelas pendekatan Realistic Mathematics Education (RME) yang berjumlah 26 peserta didik dan kelas VII 6 sebagai kelas pendekatan Saintifik yang berjumlah 26 peserta didik. Instrumen dalam penelitian ini adalah lembar tes hasil belajar yang berbentuk soal uraian. Rata-rata hasil belajar matematika peserta didik dengan pendekatan Realistic Mathematics Education (RME) adalah 53,5 sedangkan rata-rata hasil belajar peserta didik dengan pendekatan Saintifik sebesar 44,54. Penelitian ini menunjukkan bahwa hasil belajar matematika peserta didik menggunakan pendekatan Realistic Mathematics educatio (RME) lebih baik dari
\end{abstract}


hasil belajar matematika peserta didik menggunakan pendekatan Saintifik di kelas VII SMP Negeri 14 Kota Bengkulu, dengan $t_{\text {hitung }}=2,689441>t_{\text {tabel }}=2,008559$.

Kata kunci: hasil belajar matematika; pendekatan realistic mathematics education (rme); pendekatan saintifik.

\section{PENDAHULUAN}

Matematika adalah mata pelajaran yang sangat penting dalam kehidupan secara umum dan khususnya dalam pendidikan. Matematika digunakan untuk dan memberikan dasar kepada peserta didik dalam memahami mata pelajaran lain seperti fisika, ekonomi dan sebagainya. Matematika adalah pengetahuan yang selalu digunakan di dalam kehidupan sehari-hari (Rizki, 2017). Depdiknas dalam Maryani (2017) menyebutkan bahwa tujuan pembelajaran matematika adalah memahami dan menerapkan konsep, prosedur, prinsip, teorema, dan ide matematis.

Salah satu karakteristik dari matematika yaitu memiliki objek kajian yang bersifat abstrak. Karena keabstrakannya tersebut menjadikan matematika sebagai pelajaran yang ditakuti bagi sebagian besar peserta didik baik pada sekolah dasar maupun sekolah menengah. Ketakutan ini disebabkan pembelajaran yang menekankan pada penghafalan materi semata, penekanan pada kecepatan berhitung, serta kurangnya variasi dalam proses pembelajaran (Jalal, 2018). Oleh karena itu diperlukan variasi dalam proses belajar mengajar untuk mengatasi rasa takut peserta didik terhadap mata pelajaran matematika.

Kurikulum 2013 menjadikan matematika menjadi salah satu pelajaran yang diutamakan. Ini dibuktikan dari jam pelajaran yang lebih banyak dibandingkan dengan mata pelajaran lain. SMP Negeri 14 Kota Bengkulu telah menerapkan kurikulum 2013 pada kelas VII dan VIII. Tetapi fakta yang ditemukan di lapangan, pembelajaran di kelas masih menggunakan pembelajaran konvensional. Pembelajaran masih berpusat pada guru. Peserta didik masih belum aktif dalam kegiatan pembelajaran karena guru hanya menerangkan materi pelajaran di kelas. Guru belum mengaitkan materi yang akan dipelajari dengan kehidupan nyata. Peserta didik hanya menghapal rumus dan konsep dari materi yang bersifat abstrak. Hal ini menyebabkan kegiatan belajar mengajar bersifat monoton dan tidak bermakna.

Solusi yang dapat dilakukan adalah dengan menggunakan pendekatan pembelajaran yang tepat untuk meningkatkan hasil belajar peserta didik. Salah satu pendekatan pembelajaran yang dapat digunakan untuk meningkatkan hasil belajar peserta didik adalah pendekatan Realistic Mathematics Education (RME). Pendekatan Realistic Mathematics Education adalah pendekatan pembelajaran yang menggunakan masalah-masalah realistik sebagai sumber munculnya konsep-konsep matematika atau pengetahuan matematika formal yang dapat meningkatkan aktivitas penyelesaian masalah, pencarian masalah, dan pengorganisasian pokok persoalan (Lestari \& Yudhanegara, 2017). Pendekatan Realistic Mathematics Education $(R M E)$ memiliki prinsip bahwa mengajarkan matematika harus dimulai dari hal yang bersifat kontekstual, peserta didik akan lebih memahami materi matematika sehingga peserta didik akan lebih memahami materi matematika yang bersifat abstrak (Gusnarsi dkk, 2017). Implikasi dalam penerapan pendekatan Realistic Mathematics Learning (RME) adalah peserta didik memahami manfaat matematika dalam menyelesaikan masalah dalam konteks nyata, serta meningkatkan motivasi peserta didik dalam belajar sehingga dapat meningkatkan hasil belajar.

Pendekatan lain yang dapat digunakan adalah pendekatan Saintifik. Pendekatan saintifik merupakan pendekatan yang sering diterapkan dalam pembelajaran kurikulum 2013. Pendekatan saintifik memotivasi peserta didik untuk belajar dengan cara mencari tahu dari berbagai sumber melalui observasi, dan bukan hanya diberi tahu (Hosnan, 2014). Pendekatan saintifik merupakan proses pembelajaran yang dirancang sedemikian rupa agar peserta didik dapat aktif dalam mengkonstruksi konsep, hukum atau prinsip 
melalui tahapan mengamati, mengajukan hipotesis, mengumpulkan data, menganalisis data, dan mengomunikasikan (Daryanto, 2015).

Rumusan masalah dalam penelitian ini adalah: Apakah hasil belajar matematika peserta didik menggunakan pendekatan Realistic Mathematics Education (RME) lebih dari hasil belajar matematika peserta didik menggunakan pendekatan saintifik di Kelas VII SMP Negeri 14 Kota Bengkulu tahun pelajaran 2018/2019?

Tujuan penelitian ini untuk mengetahui apakah hasil belajar matematika peserta didik menggunakan pendekatan Realistic Mathematics Education (RME) lebih baik dari hasil belajar matematika peserta didik menggunakan pendekatan saintifik di Kelas VII SMP Negeri 14 Kota Bengkulu tahun pelajaran 2018/2019.

\section{METODE PENELITIAN}

Jenis penelitian yang digunakan dalam penelitian ini adalah Quasi Experiment (Eksperimen semu) dengan desain nonequivalent Posttest-Only Control Group Design. Penelitian ini menggunakan 3 kelas, yaitu kelas uji coba yang digunakan untuk menguji soal sebelum digunakan untuk penelitian, dan 2 kelas eksperimen yaitu kelas eksperimen 1 menggunakan pendekatan Realistic Mathematics Education dan kelas eksperimen 2 menggunakan pendekatan Saintifik. Populasi yang diteliti dalam penelitian ini adalah seluruh peserta didik kelas VII SMP Negeri 14 Kota Bengkulu tahun pelajaran 2018/2019. Sampel diambil dengan teknik Cluster Random Sampling sehingga didapat kelas VII 5 sebagai kelas eksperimen 1 dengan pendekatan Realistic Mathematics Education dan kelas VII 6 sebagai kelas eksperimen 2 dengan pendekatan Saintifik.

Instrumen penelitian yang digunakan dalam penelitian ini adalah tes hasil belajar matematika peserta didik. Tes hasil belajar yang diberikan adalah tes akhir dalam bentuk soal uraian yang terdiri dari 9 butir soal. Instrumen diuji coba terlebih dahulu untuk melihat validitas, reliabilitas, daya pembeda dan tingkat kesukaran instrumen tersebut sebelum digunakan untuk mengambil data penelitian.

Uji validitas butir soal menggunakan uji korelasi product moment pearson dengan rumus sebagai berikut:

$$
\begin{aligned}
& r_{x y}=\frac{N \sum X Y-\left(\sum X\right)\left(\sum Y\right)}{\sqrt{\left[N \sum X^{2}-\left(\sum X\right)^{2}\right] \cdot\left[N \sum Y^{2}-\left(\sum Y\right)^{2}\right]}} \\
& \text { (lestari \& Yudhanegara, 2017) } \\
& \text { Soal dikatakan valid apabila } 0,40 \leq r_{x y}<
\end{aligned}
$$

1.

Uji reliabilitas instrument menggunakan rumus alpha cronbach yaitu:

$$
r=\left(\frac{n}{n-1}\right)\left(1-\frac{\sum s_{i}^{2}}{s_{t}^{2}}\right)
$$

(Lestari \& Yudhanegara, 2017)

Soal dikatakan reliabel apabila $0,40 \leq r<$ 1,00 .

Uji daya pembeda soal menggunakan rumus sebagai berikut:

$$
D P=\frac{\bar{X}_{A}-\bar{X}_{B}}{S M I}
$$

(Lestari \& Yudhanegara, 2017)

Instrumen memiliki daya pembeda yang baik apabila $0,20<D P \leq 1,00$.

Uji taraf kesukaran menggunakan rumus sebagai berikut:

$$
I K=\frac{\bar{X}}{S M I}
$$

(Lestari \& Yudhanegara, 2017)

Instrument yang digunakan adalah instrument yang memiliki indeks kesukaran $0,30<I K \leq 0,70$.

Instrument yang telah melalui tahap analisis kemudian digunakan untuk mendapatkan data hasil belajar matematika kedua kelas sampel. Data hasil belajar kemudan di analisis dengan menggunakan uji t dengan prasyarat kedua data berdistribusi normal dan homogen. Uji normalitas menggunakan uji Shapiro-Wilk dan uji homogenitas menggunakan uji F. Hipotesis yang akan diuji yaitu:

$\mathrm{H}_{0}$ : Hasil belajar matematika peserta didik menggunakan pendekatan Realistic Mathematics Education (RME) kurang dari atau sama dengan hasil belajar matematika peserta didik menggunakan pendekatan Saintifik di kelas VII SMP Negeri 14 Kota Bengkulu.

$\mathrm{H}_{1}$ : Hasil belajar matematika peserta didik menggunakan pendekatan Realistic Mathematics Education (RME) lebih dari hasil belajar matematika peserta didik menggunakan pendekatan Saintifik di kelas VII SMP Negeri 14 Kota Bengkulu. 


$$
t_{\text {hitung }}=\frac{\bar{X}_{1}-\bar{X}_{2}}{\sqrt{\frac{\left(n_{1}-1\right) s_{1}^{2}+\left(n_{2}-1\right) s_{2}^{2}}{n_{1}+n_{2}-2}} \sqrt{\frac{n_{1}+n_{2}}{n_{1} \cdot n_{2}}}}
$$

Rumus uji t yang digunakan adalah sebagai

(Lestari \& Yudhanegara, 2017)

\section{HASIL DAN PEMBAHASAN \\ Hasil}

Penelitian ini dilaksanakan di SMP Negeri 14 Kota Bengkulu kelas VII 5 dan kelas VII 6 yang dilaksanakan pada tanggal 18 Februari - 30 April 2018. Penelitian dilaksanakan dalam 14 pertemuan, yaitu 7 pertemuan pada kelas eksperimen 1 dengan menggunakan pendekatan Realistic Mathematics Education (RME) dan 7 pertemuan pada kelas eksperimen 2 dengan menggunakan pendekatan Saintifik.

Soal posttest diberikan pada pertemuan ke7 setiap kelas sampel. Sebelum posttest diberikan diujicoba terlebih dahulu dan dinanalisis untuk mengetahui validitas, reliabilitas, daya pembeda dan tingkat kesukaran soal tersebut.

\begin{tabular}{|c|c|c|c|c|}
\hline \multirow{2}{*}{ No } & Validitas & \multirow{2}{*}{ Reliabilitas } & $\begin{array}{c}\text { Daya } \\
\text { Pembeda }\end{array}$ & $\begin{array}{c}\text { Indeks } \\
\text { Kesukaran }\end{array}$ \\
\hline & kriteria & & Kriteria & Kriteria \\
\hline 1 & Valid & \multirow{9}{*}{ Reliabel } & Cukup & Sedang \\
\hline 2 & Valid & & Cukup & Sedang \\
\hline 3 & Valid & & Cukup & Sukar \\
\hline 4 & Valid & & Baik & Sedang \\
\hline 5 & Valid & & Cukup & Mudah \\
\hline 6 & Valid & & Baik & Sedang \\
\hline 7 & Valid & & $\begin{array}{c}\text { Sangat } \\
\text { Baik }\end{array}$ & Sedang \\
\hline 8 & Valid & & Baik & Sedang \\
\hline 9 & Valid & & Baik & Sedang \\
\hline
\end{tabular}

Tabel 1. Rekapitulasi Hasil Uji Coba

Berdasarkan Tabel 1 soal nomor 1, 2, 4, 6, 7, 8, dan 9 dapat digunakan karena telah memenuhi kriteria. Soal nomor 3 dan 5 memiliki indeks kesukaran sukar dan mudah sehingga soal tersebut harus direvisi sebelum digunakan.

Soal yang telah direvisi kemudian diberikan kepada kedua kelas sampel pada pertemuan terakhir. Deskripsi hasil belajar kelas RME dan kelas Saintifik dapat dilihat pada Tabel 2.

Tabel 2. Deskripsi Hasil Belajar

\begin{tabular}{|l|c|c|}
\hline & RME & Saintifik \\
\hline Jumlah siswa & 26 & 26 \\
\hline $\begin{array}{l}\text { Jumlah nilai } \\
\text { siswa }\end{array}$ & 1391 & 1158 \\
\hline Rata-rata & 53,5 & 44,54 \\
\hline Nilai Terendah & 32 & 22 \\
\hline Nilai Tertinggi & 81 & 70 \\
\hline Standar Deviasi & 13,503 & 10,312 \\
\hline Varians & 182,340 & 106,338 \\
\hline
\end{tabular}

Data hasil belajar siswa pada Tabel 2 menunjukkan bahwa rata-rata nilai pada kelas eksperimen 1 adalah 53,5 sedangkan pada kelas eksperimen 2 adalah 44,54. Nilai tertinggi pada kelas Eksperimen 1 adalah 81 dan nilai terendah pada kelas ini adalah 32 Nilai tertinggi pada kelas Eksperimen 2 adalah 70 dan nilai terendah pada kelas ini adalah 22. Jumlah nilai kelas eksperimen 1 adalah 1391 sedangkan pada kelas eksperimen 2 sebesar 1158.

Berdasarkan hasil posttest dari kelas eksperimen 1 dan kelas eksperimen 2, maka data yang diperoleh disusun menjadi sebuah data yang akan digunakan untuk uji hipotesis. uji prasyarat yang dilakukan yaitu uji normalitas dan uji homogenitas sebelum uji hipotesis dilaksanakan. Uji persyaratan ini dilakukan dengan tujuan untuk menentukan uji hipotesis yang sesuai dengan data hasil belajar kelas eksperimen 1 dan kelas eksperimen 2.

Hasil uji normalitas pada data hasil belajar kelas eksperimen 1 diperoleh $\mathrm{T}_{3}=0,963$ sedangkan pada kelas eksperimen 2 diperoleh $\mathrm{T}_{3}$ $=0,958$. Nilai $\mathrm{T}_{3}$ dari kelas eksperimen 1 dan kelas eksperimen 2 lebih dari P-value 0,920 yang menunjukkan bahwa data hasil belajar kelas eksperimen 1 dan data hasil belajar kelas eksperimen berdistribusi normal.

Uji homogenitas menggunakan uji Fisher didapat $\mathrm{F}_{\text {hitung }}=1,7147$ dengan $\mathrm{F}_{\text {tabel }}=1,9554$. Karena $F_{\text {hitung }} \leq \mathrm{F}_{\text {tabel }}$ maka varians data hasil belajar kedua sampel homogen.

Uji persyaratan analisis menunjukkan bahwa data kedua kelas sampel berdistribusi normal dan homogen sehingga dilakukan pengujian hipotesis dengan menggunakan uji $t$ dengan taraf 
signifikansi $5 \%$ atau 0,05 . Berdasarkan pengujian tersebut didapat $t_{\text {hitung }}=2,689441$ dan $t_{\text {hitung }}=$ 2,008559. Karena $t_{\text {hitung }}>t_{\text {tabel }}$ maka dapat disimpulkan bahwa hasil belajar matematika peserta didik menggunakan pendekatan Realistic Mathematics Education (RME) lebih dari hasil belajar matematika peserta didik menggunakan pendekatan Saintifk di kelas VII SMP Negeri 14 Kota Bengkulu.

\section{Pembahasan}

Proses pembelajaran di kelas eksperimen 1 dan kelas eksperimen 2 dilaksanakan 6 kali pertemuan dan 1 kali pertemuan untuk posttest untuk masing-masing kelas sampel. Pada kelas eksperimen 1 diterapkan pembelajaran dengan pendekatan Realistic Mathematics Education (RME). Pendekatan pembelajaran Realistic Mathematics Education (RME) terdiri dari 4 langkah pembelajaran, yaitu mengamati masalah kontekstual, menyelesaikan masalah kontekstual, membandingkan dan mendiskusikan jawaban, dan menarik kesimpulan. Pendekatan Saintifik diterapkan pada kelas Eksperimen 2. Pendekatan Saintifik memiliki 5 langkah pembelajaran yaitu mengamati, menanya, mengumpulkan informasi, menalar, dan mengkomunikasikan. Selama proses pembelajaran di masing-masing kelas peserta didik terlibat langsung pada setiap langkah pembelajaran sehingga membuat peserta lebih aktif dalam pembelajaran.

Kegiatan pembelajaran kelas eksperimen 1 yang pertama adalah guru membagikan LKPD kepada masing-masing kelompok. Kemudian siswa melakukan pengamatan dari LKPD yang telah diberikan. Kegiatan mengamati pada kelas eksperimen 1 merupakan kegiatan mengamati masalah kontekstual yang terdapat di LKPD.

Kegiatan mengamati pada kelas eksperimen 1 merupakan pengamatan terhadap masalah yang berhubungan dengan kehidupan sehari-hari. Karakteristik yang tercermin dari kegiatan ini adalah Phenomenological Exploration or Use Context. Masalah yang difokuskan langsung terhadap kehidupan sehari-hari dapat membuat siswa lebih termotivasi dalam belajar sehingga siswa lebih mudah dalam memahami materi yang sedang dipelajari.

Kelas Eksperimen 2 juga dibagikan LKPD secara berkelompok. Selanjutnya siswa melakukan kegiatan mengamati. Siswa secara berkelompok mengamati konsep matematika yang disajikan guru melalui LKPD. Kegiatan mengamati pada kelas eksperimen 2 merupakan kegiatan mengamati berupa konsep yang dipelajari.

Pembelajaran pada kelas eksperimen 1 dan kelas eksperimen 2 berpusat kepada siswa. Sehingga siswa menemukan sendiri konsep yang dipelajari tanpa diberi tahu oleh guru. Kegiatan menemukan konsep pada kelas eksperimen 1 dibimbing melalui benda-benda konkret seperti pada Gambar 2.

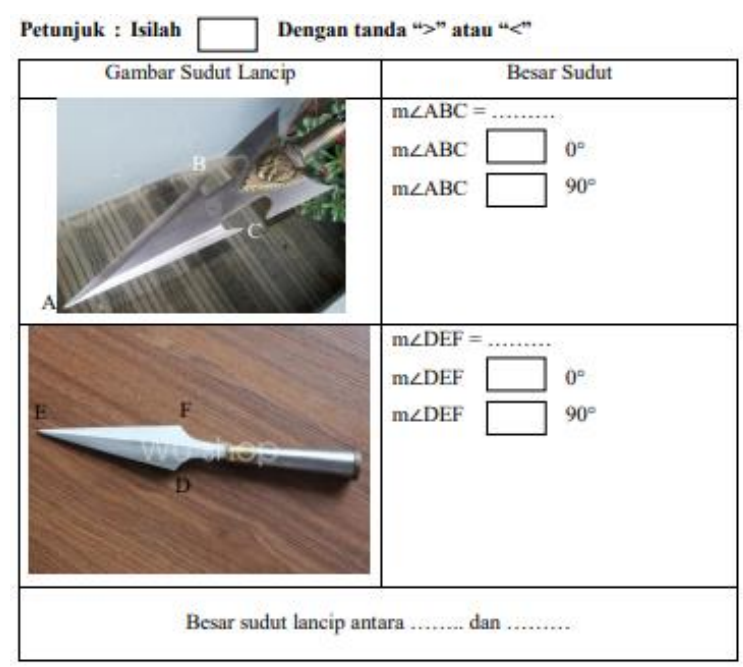

Gambar 1. Kegiatan Menyelesaikan Masalah Kontekstual Kelas Eksperimen 1

Gambar 1 menunjukkan salah satu proses siswa menemukan konsep, yaitu menemukan konsep sudut lancip. Sudut lancip digambarkan dengan sudut yang terdapat pada pisau atau tombak. Ini merupakan salah satu prinsip dari RME yaitu didactical phenomenology dimana siswa memahami suatu masalah melalui benda konkret tanpa memerlukan penjelasan (Gravemeijer, 1994).

Kelas eksperimen 2 menemukan konsep pada tahap mengumpulkan informasi. Kelas eksperimen 2 menemukan konsep dengan membaca literasi dari berbagai sumber dan mengisi bagian kosong pada LKPD. 


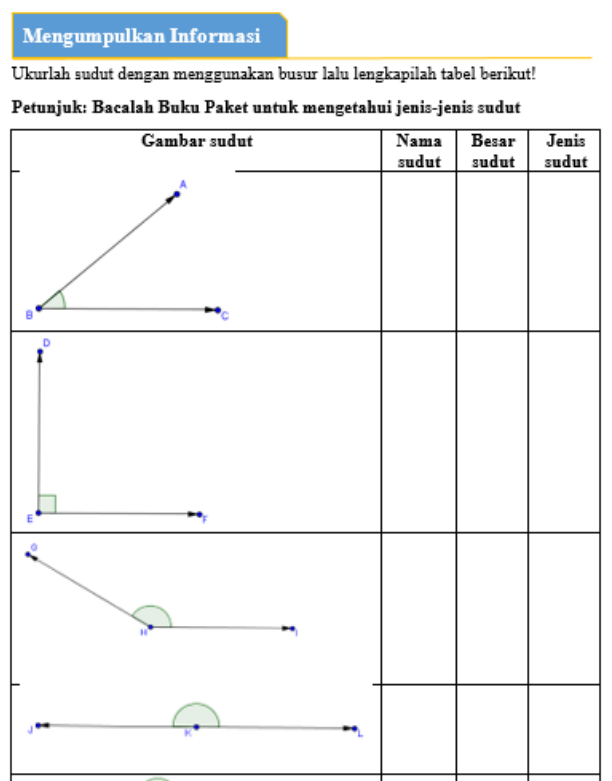

Gambar 2. Kegiatan Mengumpulkan Informasi Pada Kelas Eksperimen 2

Berbeda dengan kelas eksperimen 1, kelas eksperimen 2 penemuan konsep dilakukan dengan membaca buku dan literasi lainnya. Ini sesuai dengan karakteristik pendekatan saintifik yaitu melibatkan keterampilan proses sains dalam mengkonstruksi konsep, hukum atau prinsip.

Setelah menemukan konsep melalui LKPD, kemudian peserta didik pada kelas eksperimen 1 menyelesaikan masalah yang telah mereka pahami di awal pembelajaran. Siswa menyelesaikan masalah tersebut menggunakan pengetahuan yang telah dia dapatkan. Setiap kelompok dituntut untuk menyelesaikan masalah kontekstual yang terdapat pada LKPD.

Peserta didik pada kelas eksperimen 2 juga menyelesaikan masalah setelah menemukan konsep. Siswa pada kelas eksperimen 2 menemukan konsep pada tahapan menggali informasi. Selanjutnya siswa menyelesaikan masalah yang pada kegiatan menalar.

Kegiatan selanjutnya yaitu membandingkan dan mendiskusikan jawaban pada kelas eksperimen 1. Pada kegiatan ini salah satu kelompok diminta untuk menyampaikan hasil diskusi kelompoknya ke depan kelas untuk dibandingkan dalam diskusi kelas. Setiap kelompok dipersilahkan untuk menanggapi hasil penyelesaian masalah yang dipaparkan oleh kelompok penyaji. Sedangkan kegiatan pada kelas eksperimen 2 yaitu mengkomunikasikan. Pada tahap ini salah satu kelompok ditunjuk untuk menjelaskan hasil diskusi kelompoknya. Setelah kelompok penyaji mempresentasikan hasil diskusinya, kelompok lain dipersilahkan untuk meanggapi hasil presentasi. Setelah itu siswa bersama guru menyimpulkan hasil pembelajaran.

Kegiatan terakhir pada kelas eksperimen 1 adalah menarik kesimpulan. Setiap kelompok diminta untuk menyimpulkan hasil pembelajaran menurut kelompoknya masing-masing. Guru meminta salah satu siswa untuk membacakan kesimpulan yang telah dibuat kemudian guru menanggapi dan menyampaikan kesimpulan secara umum. Sedangkan pada kelas eksperimen 2 guru bersama siswa menyimpulkan hasil pembelajaran setelah kegiatan mengkomunikasikan.

Hasil belajar peserta didik didapat dari hasil posttest. Posttest diberikan setelah 6 pertemuan pada masing-masing kelas sampel. Berdasarkan hasil posttest didapat nilai rata-rata postes kelas eksperimen 1 dengan pendekatan Realistic Mathematics Education (RME) adalah 53,5 sedangkan pada kelas eksperimen 2 dengan pendekatan Saintifik didapat nilai rata-rata 44,54. Rekapitulasi hasil belajar siswa dapat dilihat pada Gambar 3.

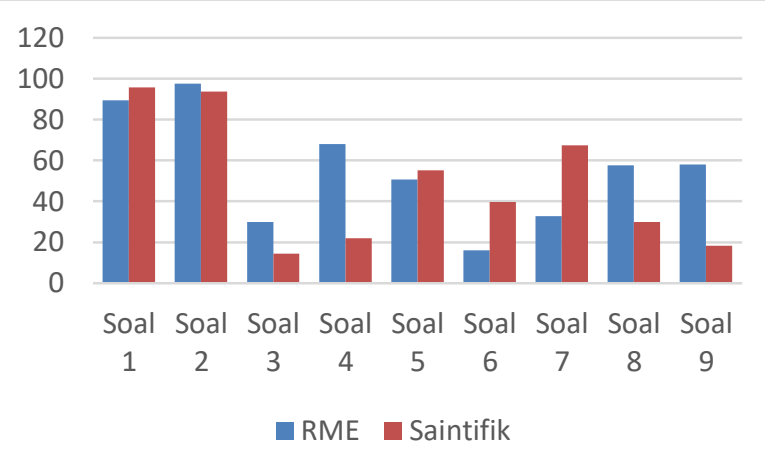

Gambar 3. Rekapitulasi hasil belajar siswa

Berdasarkan gambar 3 jawaban posttest kelas eksperimen 1 lebih unggul secara signifikan pada soal nomor 4. Persentase jawaban benar nomor 4 kelas eksperimen 1 adalah $68,05 \%$ sedangkan persentase jawaban benar kelas eksperimen 2 adalah 21,89\%. Persentase jawaban soal nomor 4 kelas eksperimen 1 dan kelas eksperimen 2 memiliki 
selisih yang cukup besar yaitu 46,16\%. Kelas eksperimen 1 lebih unggul dibanding kelas eksperimen 2 pada soal nomor 2, 3, 4, 8, dan 9 . Sedangkan kelas eksperimen 2 lebih unggul dibanding kelas eksperimen 1 pada soal nomor 1 , 5, 6, dan 7. Hasil belajar siswa kelas eksperimen 1 dan eksperimen 2 tidak jauh berbeda pada soal nomor $1,2,3$, dan 5 .

Hasil analisis deskriptif menunjukkan bahwa hasil belajar matematika siswa yang menggunakan pendekatan Realistic Mathematics Education (RME) lebih dari hasil belajar matematika siswa yang menggunakan pendekatan Saintifik di kelas VII SMP Negeri 14 Kota Bengkulu. Hasil penelitian ini relevan dengan hasil penelitian Wibowo (2017:9) yang menyatakan bahwa pendekatan realistik lebih efektif dari pendekatan saintifik terhadap prestasi belajar, kemampuan penalaran matematis dan minat belajar siswa. Nilai rata-rata kelas eksperimen 1 yang menggunakan pendekatan Realistic Mathematics Education (RME) adalah 53,5. Sedangkan nilai rata-rata kelas eksperimen 2 yang menggunakan pendekatan Saintifik adalah 44,54. Nilai maksimum pada kelas eksperimen 1 adalah 81 dan dan nilai minimum 32. Sedangkan nilai maksimum pada kelas eksperimen 2 adalah 70 dan nilai minimum 22.

\section{KESIMPULAN}

Berdasarkan penelitian yang telah dilakukan terhadap peserta didik kelas VII SMP Negeri 14 Kota bengkulu dapat disimpulkan bahwa hasil belajar matematika peserta didik dengan pendekatan Realistic Mathematics Education $(R M E)$ lebih dari hasil belajar matematika peserta didik dengan menggunakan pendekatan Saintifik di kelas VII SMP Negeri 14 Kota Bengkulu tahun pelajaran 2018/2019. Hal ini ditunjukkan dari hasil uji-t didapatkan $t_{\text {hitung }}=$ 2,69 dengan $t_{\text {tabel }}=2,01$. Karena $t>t_{\text {tabel }}$ maka $\mathrm{H}_{0}$ ditolak.

\section{DAFTAR PUSTAKA}

Daryanto. (2014). Pendekatan Pembelajaran Saintifik Kurikulum 2013. Yogyakarta: Penerbit Gava Media.

Gravemeijer, K. P. E. (1994). Developing Realistic Mathematics Education. Utrecht: Freudenthal Institute.
Gusnarsi, dkk. (2017). Pengaruh Pendekatan Realistic Mathematics Education (RME) Terhadap kemampuan Penalaran Matematis Siswa Pada Materi Lingkaran Kelas VIII. Jurnal Pendidikan Matematika Indonesia. 2 (1): 32-36.

Hosnan, M. (2014). Pendekatan Saintifik dan Kontekstual dalam Pembelajaran Abad 21. Bogor: Ghalia Indonesia.

Isrok'atun, \& Rosmala, A. (2018). ModelPendekatan Matematika. Jakarta: Bumi Aksara.

Jalal, A. (2018). Kolaborasi RME (Realistic Mathematics Education) dengan TGT (Team Games Tournament) Untuk Meningkatkan Aktivitas dan Hasil Belajar. Jurnal Axioma. 3 (1): 97-111.

Lestari, K. E., \& Yudhanegara, M. R. (2017). Penelitian Pendidikan Matematika, Bandung: Refika Aditama

Maryani, dkk. (2017). Perbandingan Hasil Belajara Matematika Siswa Antara Pendekatan Kooperatif Tipe Group Investigation dan Student Teams Achievement Division. JP2MS. 1 (1): 54-59.

Rizki, Lidya Dita dkk. (2017). Perbandingan hasil Belajar Dengan Menggunakan Media Manipulatif Dengan Pembelajaran Konvensional. JP2MS. 1 (1): 47-53.

Wibowo, A. (2017). Pengarruh pendekatan pembelajaran matematika realistik dan Saintifik terhadap prestasi belajar, kemampuan penalaran matematis, dan minat belajar. Jurnal Riset Pendidikan Matematika, 4(1):1-10. 